\title{
Effectiveness of Multimedia in the Development of Teachers Training Institutes at Tertiary Level in Khyber Pakhtunkhwa, Pakistan
}

\author{
Qaiser Suleman \\ M.Phil (Education) Scholar, Institute of Education \& Research, Kohat University of Science \\ \& Technology, Khyber Pakhtunkhwa, (Pakistan) \\ Email: Look_for_reality@yahoo.com \\ Zulfiqar Ali Behan \\ Assistant Professor, Govt. Elementary College of Education Lyari, Karachi \\ E.mail: zulfiqarbehan@gmail.com \\ Dr. Ishtiaq Hussain \\ Assistant Professor, Institute of Education \& Research, Kohat University of Science \& \\ Technology, Khyber Pakhtunkhwa, (Pakistan) \\ Email: dr.ishtiaqkust@gmail.com
}

Azra Fanoos

M.Phil (Education), Institute of Education \& Research, Kohat University of Science \& Technology, Khyber Pakhtunkhwa, (Pakistan)

\section{Sadia Ambreen}

M.Phil (Education), Institute of Education \& Research, Kohat University of Science \& Technology, Khyber Pakhtunkhwa, (Pakistan)

Accepted: July 24, 2012 Published: November 12, 2012

Doi:10.5296/ijld.v2i6.2667 URL: http://dx.doi.org/10.5296/ijld.v2i6.2667

\begin{abstract}
The purpose of the study was to explore the effectiveness of multimedia in the development of teachers training institutes at tertiary level in Khyber Pakhtunkhwa. All the student teachers studying in public and private teachers training institutes at tertiary level in Khyber Pakhtunkhwa constituted the population of the study. The study was delimited to the student teachers of Kohsar Public Schools \& College Latamber (Karak) and Hussan Model Degree College Chokara (Karak). Forty student teachers of B.Ed level from these two institutions were selected as sample of the study. Sample student teachers were divided into two groups i.e. control group and experimental group on the basis of pre-test. Each group was comprised of 20 student teachers. The study was experimental in nature therefore Pre-test-Post-test Equivalent Groups Design was used as research instrument. After analysis
\end{abstract}


of the data, it was concluded that multimedia plays a fundamental role in teaching of teacher training programmes at tertiary level. Multimedia was found to be more effective in clarifying difficult concepts of the student teachers. The students of experimental group showed excellent performance as compared to the students of control group. Based on findings, it was strongly recommended that multimedia should be provided to each institutes. Furthermore it should be utilized in teachers training institutes effectively.

Keywords: Effectiveness, multimedia, development, teacher training institutes, tertiary level

\section{Introduction}

Teacher education is playing a vital and crucial role in reforming and strengthening the society and is directly responsible to the development of a nation. It is an instrument which is used to change the social, economic, cultural and political system of the country. Since teacher education is system which prepares competent, talented and professionally skilful teachers which in turn produce talented individual for the development of nation. Therefore, teacher education has the most crucial position in the entire system of education. So it is imperative to pay proper attention to make teacher education more effective and successful. Government of Pakistan (1959) stated that "No education system is better than its teachers". Keeping in the view about statement it is right to say that a teacher plays a very crucial role in the nation building. So it is imperative that the teacher should be competent and professionally skilful.

Educational technologies play a fundamental role in strengthening and enhancing teaching learning process. Multimedia helps in increasing student's interest and participation in teaching learning process. Multimedia is the combination of various media used to display presentation or lectures easily. According to Rouet, Levonen, \& Biardeau (2001), multimedia is defined as the combination of a variety of digital media types such as text, images, sound and video, which combine to shape an integrated multi-sensory interactive application or public presentation. Kline (1994) stated that multimedia is beneficial for pre-service teacher education programmes. A number of studies indicate that computer-based multimedia can improve learning and retention of material presented during a class session or individual study period, as compared to "traditional teaching method or study materials in which multimedia is not utilized (Fletcher, 2003; Mayer, 2001).

The principal researcher is presently studying at the Institute of Education \& Research, Kohat University of Science and Technology Kohat. Therefore he was interested to conduct a study to explore the effectiveness of the Multimedia in the development of teachers training institutes at tertiary level. The researchers expect that the findings of the study will definitely help the teachers to be aware of the effectiveness and usefulness of multimedia in teaching learning process in teachers training institutes at tertiary level. In this way they will utilize multimedia to strengthen and improve their teaching outcomes.

\section{Review of Related Literature}


The review of related literature of this paper has been divided into two sections. Section - A is about the Teacher Education and Section - B is about the Multimedia. Therefore, these two sections are explained separately.

\section{Teacher Education}

\section{Section - A}

Teacher Education is a system of education, which deals with the study of teaching learning process and its application to the education of people. The main purpose of teacher education is to develop and build up an understanding of the theoretical basis of education and its role in society, and the factors, which affects teaching strategies, learning process and educational processes. It also plays a vital and crucial role in developing a plan, its implementation, in evaluation of appropriate curriculum and learning programmes. It also involves in the assessment and reporting of the student's achievement. Teacher education is directly responsible to prepare professionally experienced and competent teachers to perform effective role and function according to the needs, demands and requirements of the society.

According to Farrant (1990), the quality of every formal system of education depends on the quality of teachers who perform their duties in the same system. Therefore, teacher education is vital and important. Teacher education is considered not only teaching of a teacher but also it stimulates and encourages his initiative, to keep it alive, to reduce the problems of the unplanned process and to save his time, to reduce his trouble and money and the taught (Sheikh \& Rasool, 1998). Teacher education is considered as the knowledge, abilities and the skills, which is relevant to the teacher's life. A course of teacher education should be designed to reshape the attitudes and manners, to remold the habits and in a way to reconstitute the teacher personality (AIOU, 2000, p.22). According to Aggarwal (1993), "teacher education consists of all those competencies (knowledge, facts, skills and abilities) which deal with the teacher's life as a teacher". Teacher education is composed of policies, plannings and procedures designed to train the prospective teachers and equip them with requied the knowledge, behaviours, attitudes, and skills so that they may be able to perform their dutites effectively in the classrooms, schools and wider community (Free online Wikipedia). According to Norton (1985), teacher education refers to the structures, instructions and process by which men and women are equipped and prepared for job in elementary and secondary schools. It is formal and informal instructions and training, which is necessary for the entrance to teaching profession.

The aim of teacher education is not to teach the teachers how to teach, but it is a training to develop the natural abilities and potentialities of teachers, to make them dynamic and to make them expertise to produce fruitful teaching results with the minimum application of energies, time and capital (Shahid, 2007). According to Encyclopedia of Education, teacher education is an education and preparation of individuals enabling them to become professional teachers (Frank \& Wagnalls, 1987). Teacher education consists of all formal and non-formal activities and experiences that assist a person to presume the responsibilities of a member of the educational profession or to fulfill his responsibilities more effectively and 
successfully (Good, 1973). Bennet (2000) pointed out that teacher education needs to be more dynamic. He also argued that in order to progress with the technological revolution in society, the teacher education programmes must be properly designed and planned at all levels so that it may produce extremely educated, scientific and logical minded, uncompromising on quality, innovative, courageous but shows sympathy towards their students.

Iqbal (1996) explained that not only the effectiveness of the teacher training is important but also it should be made according to the value system of society. It is imperative that the teacher education should be designed and directed in accordance with the doctrines and values of its faith. Teacher training should satisfy the production of teachers who possess sound personal characters, act according to Shariah and a model personality for the students. Shahid (2007) stated that education system of a nation is the reflection of academic and professional abilities of its teachers. The quality of education depends on teacher's abilities and capabilities and it is an international fact that the teachers are the builder of the nations and they are responsible for the building of future of their nations.

\section{Aims and Objectives of Teacher Education}

Zeichner (1983) stated that the basic aim of teacher education is to prepare prospective teachers, competencies for insightful and reflective actions and assist them to test and examine the moral, ethical, political and the instrumental issues that are entrenched in their everyday thinking and practice. He described specific goals of a teacher's education program for graduates in which they should be skillful, competent and expertise. The teacher education should create a teacher with:

- The abilities to analyze the students' abilities and competencies

- The abilities to analyze instructional programmes

- The abilities and skills to analyze environmental conditions

- The knowledge and ability to analyze learning difficulties

- The abilities and knowledge to define objectives

- To know the various learning styles and types

- The abilities to manage instructional space, resources, time and teaching process and conduct of students

- The abilities to determining the sequence of instruction

- The abilities and knowledge to evaluate the progress of the students

- The abilities and skills to make use of educational research

- The abilities to analyze data related to diagnosing and planning of instructions

- The abilities to participate in professional associations enthusiastically

According to Aggarwal (1988), the aims and objectives of teacher education are as under:

- To develop the teacher's ability to take care of himself so that he may be able to regulate himself with different physical circumstances and social setting

- To develop of the teacher's ability to become a child with children and an adult with adults

- To develop the teacher's ability to be a responsible citizen 
- To develop the teacher's ability to have good command and control of the subject content handed over to him in the school

- To develop the skills, expertise and experiences of the teachers

- To develop the teacher's ability to do, to observe, to deduce and to generalize

- To develop concentration and attentiveness to maximize the achievements from both human and material resources

Besides, Government of Pakistan (1995) declared that the aims and objectives of teacher education are as under:

- To familiarize the prospective teachers with foundations of education and learning theories

- To equip and furnish the prospective teachers with instructional skills and make them familiar with basic curriculum designing and planning

- To familiarize prospective teachers with modern and contemporary teaching methods and principles with special emphasis on children's participation and creativity in teaching learning process.

\section{Teaching Training Institutes in Khyber Pakhtunkhwa}

In Khyber Pakhtunkhwa Province, there are total 83 teacher training institutes out of which twenty eight (28) institutes are controlled and managed by the public sector and the rest are managed by the private sector. These teachers training institutes offer various teacher training programmes. Three institutes offer Ph.D, five institutes offer M.Phil and thirty five institutes offer M.Ed. In addition, most of the teacher training institutes conduct B.Ed, C.T and P.T.C programmes. Some institutes offer short courses in pedagogy, subject content training and information technology for in-service teacher (DCTE, Khyber Pakhtunkhwa, Abbottabad, 2009).

\section{Multimedia}

\section{Section - B}

The term multimedia is the set of different technologies, which are used for the purpose of communication through a combination of visual and audio media in new ways. It is used for different purposes i.e., entertainment, advertising and education. Multimedia often refers to technologies of computer. Now-a-days every PC supports multimedia because they have CD-ROM or DVD drive, a good sound card and video card usually installed in main board. However, the term multimedia also describes a number of dedicated media devices, such as Digital Video Recorders (DVDs) interactive television, MP3 Players, advanced wireless devices and public video displays. Multimedia is the combination of several types of media, which consists of text, video, audio, graphics, etc. For example, a presentation, which is presented with audio and video clips, is considered a multimedia presentation (Vallikkad, 2009).

Media combinations are generally considered as multimedia system. Multi-mediation means 'many-media'. The term multimedia instructional system' refers to the applications of 
the set of diverse learning experiences that are presented to the students by the use of selected teaching strategies in order to strengthen one another to ensure the learners' achievement of the pre-determined and desired behavioral objectives. According to Venkataiah (1996), multimedia is defined as more than one either medium used in a single communication in sequence or simultaneously. Sometimes, instructional situations need the application of more than one media for the achievement of objectives. The application of more than one media aids in conveying message to the learners for all practical purposes that are not possible through single medium. Most learning events, if not all, are multi-mediated. Systematically planned, multi-mediated learning events are more predictable of product, are more effectively refineable and are easier to produce and control than single mediated learning events.

According to Lewis and Hosie (1994), multimedia was particularly useful in situations where there were large number of learners distributed over time and place, where learners had varied experiences and skills and where there was a shortage of teachers with subject matter expertise. In addition, they claimed that multimedia was ideal when there was a need for simulation, continuous practice or retraining; the problems of combining different learning media such as text, slides, video and audio; where subject matter was stable, and when training involved processes, procedures, problem-solving and decision making. Kline (1994) proposed that multimedia gave the answer to a tough situations faced by teacher educators, i.e., the need to provide opportunities for pre-service students to observe children, so that they become trained and skillful in analyzing the behaviour of the children. For example, field visits to classroom settings can be time consuming, not easy to organize and often disturbing and interfering for schools and children. The precision of students written accounts noted during such visits cannot easy to determine. Salinger (2004) claimed that ICT can enhance the quality of education because the content of multimedia helps in explaining difficult concepts applying methods which are not accessible through traditional methods of learning.

\section{Statement of the Problem}

Educational technology plays a vital role in teaching learning process and makes it more interesting, productive, effective and successful. That is why the study in hand was conducted to ass the effectiveness of multimedia in teachers training institutes at tertiary level. Therefore the statement of the problem was designed as "Effectiveness of Multimedia in the Development of Teachers Training Institutes at Tertiary Level in Khyber Pakhtunkhwa, Pakistan”.

\section{Objectives of the Study}

The objectives of the study were:

a) to find out the effects of multimedia on the academic achievement of student teachers at tertiary level;

b) to determine whether teaching through multimedia is more effective than the traditional method of teaching at tertiary level; 
c) to examine the effects of multimedia on the academic achievement of higher and low achievers;

d) to investigate whether the student teachers can retain the learning for a longer time when they taught through multimedia; and

e) to suggest workable recommendations to enhance the teaching learning process through multimedia and other technologies.

\section{Hypotheses of the Study}

To achieve the above mentioned objectives of the study, the following null hypotheses were designed:

1. There is no significant different between the performance of control and experimental groups on pre-test.

2. There is no significance difference between the performance of high achievers of the control and experimental groups on pre-test.

3. There is no significant difference between the performance of low achievers of the control and experimental groups on pre-test.

4. There is no significant difference between the performance of the control and experimental groups on post-test.

5. There is no significant difference between the performance of high achievers of control and experimental groups on post-test.

6. There is no significant difference between the performance of low achievers of control and experimental groups on post-test.

7. There is no significant difference between the performance of control and experimental groups on retention test.

8. There is no significant difference between the performance of low achievers of control and experimental groups on retention test.

9. There is no significant difference between the performance of high achievers of control and experimental groups on retention test.

\section{Research Methodology}

\section{Participants}

All the student teachers studying in all public and private teachers training institutes at tertiary level in Khyber Pakhtunkhwa constituted the population of the study. Forty student teachers from two institutes Kohsar Public Schools \& College Latamber (Karak) and Hussan Model Degree College Chokara (Karak) at B.Ed level were selected through simple random sampling technique.

\section{Delimitations of the Study}

The study was delimited to the student teachers of Kohsar Public Schools \& Colleges Latamber (Karak) and Hussan Model Degree College Chokara (Karak) of B.Ed level. The study was further delimited to the subject of Teacher Education teaching at B.Ed level. The following units of Teacher Education were taught during the experiment: 


\begin{tabular}{|c|c|c|c|}
\hline Units & Title of the Units & Units & Title of the Units \\
\hline 01 & Teacher Education: Introduction & 03 & $\begin{array}{l}\text { Evolution of Teacher Education in } \\
\text { Pakistan }\end{array}$ \\
\hline 02 & Comparative Teacher Education & 04 & Teaching Methods and Techniques \\
\hline
\end{tabular}

\section{Research Design}

As the study was experimental in nature therefore "The Pre-test-Post-test Equivalent Groups Design" was used. According to this design, subjects are randomly allocated to exeperimental and control groups. Following is the symbolic representation of the design:

$\begin{array}{llllll}\mathbf{R} & \mathbf{E} & = & \mathbf{O 1} & \mathbf{T} & \mathbf{O 2} \\ \mathbf{R} & \mathbf{C} & = & \mathbf{O 3} & & \mathbf{O 4}\end{array}$

Where

$$
\begin{array}{ll}
\mathrm{R}=\text { Randomly selected } & \mathrm{E}=\text { Experimental Group } \\
\mathrm{C}=\text { Control Group } & \mathrm{O}=\text { Observation or Mearsurement } \\
\mathrm{T}=\text { The experimental treatment } &
\end{array}
$$

\section{Research Instrumentation}

The study was experimental in nature therefore, the researchers thought it better to select pre-test and post-test technique as research instrument for data collection. To compare the performance of the both groups i.e. control group and experimental group, a question paper was prepared in the four chapters of teacher education and than administered among the students of both groups before the treatment. Similarly, another paper was prepared which was administered among the students of both groups after treatment. These two question papers were used as a research instrument.

\section{Data Collection}

In order to collect data, the researchers administered a pre-test and then a post-test to the both groups. The principal researcher along with other two teachers, administered pre-test and post-test. For this purpose, two question papers were developed covering the four units of Teacher Education. In this way data was collected.

\section{Data Analysis}

For the anyalysis of the data, raw scores obtained from both test i.e. pre-test, and post-test were presented in tabular form. For the satistical analysis of the data, the mean, standard deviation and differences of means were computed for each group. Significance of difference between the mean scores of both the experimental and control groups on the variable of pre-test scores and post test scores was tested at 0.05 level by applying t-test. The following formulae were used for the analysis of data:

\section{Mean Formula}

Mean of the data was calculated by the following formula: 


$$
\text { Mean }=\bar{X}=\frac{\sum f x}{\sum f}
$$

Where

$$
\bar{X}=\text { Mean } \quad \mathrm{X}=\text { data } \quad \mathrm{f}=\text { Frequencies }
$$

\section{Standard Deviation Formula}

Standard Deviation of the data was calculated by the following formula:

$$
\mathrm{SD}=\sqrt{\frac{\sum X^{2}-\frac{\left(\sum X\right)^{2}}{N}}{N-1}}
$$

Where $\mathrm{N}$ stands for Total no of frequencies/respondents

\section{T-Test Formula}

For $\mathrm{t}$-test the following formula was used to find out the value of $\mathrm{t}$ :

$$
\begin{aligned}
\mathbf{t} & =\frac{\overline{X_{1}}-\overline{X_{2}}}{\sqrt{\left(\frac{S S_{1}+S S_{2}}{n_{1}+n_{2}-2}\right)\left(\frac{1}{n_{1}}+\frac{1}{n_{2}}\right)}} \\
\text { Where } \quad \mathrm{SS} & =\sum X^{2}-\frac{\left(\sum X\right)^{2}}{N}
\end{aligned}
$$

\section{Appointment of the Teachers for Experimentation}

For this experiment, two teachers having equal qualifications and teaching experience were appointed to teach the both groups i.e control group and experimental group. It was a tiring and difficult situation for the researchers to provide equally qualified and experienced teachers. After great efforts, the researchers succeeded in providing teachers having equal qualifications and experience. Their qualifications were M.A English and M.Ed.

\section{Training of Teacher in Using Multimedia}

Research studies have shown that majority of the teachers are not trained for the effective utilization of educational technologies for instructional process (Suleman, et all, 2011). Therefore, it was necessary to train the teacher for the effective utilization of multimedia. For this purpose, one day training was given to the teacher teaching to experimental group.

\section{Analysis and Interpretation of Data}

The purpose of this research study was to explore the effectiveness of multimedia in the development of teachers training institutes at tertiary level in Khyber Pakhtunkhwa. In order to break up the sample in two groups i.e. control group and experimental group, a pre-test was administered. On the basis of the said test sample was classified into control group and experimental group. Both the groups were taught through usual method by two 
teachers of the same qualifications and teaching experience. During the experiment, multimedia was used only for the experimental group. This experiment was continued for six weeks. After the completion of the experiment, data was collected, organized, tabulated, analyzed and compared. The whole process is described as under:

Ho 1: There is no significant different between the performance of control and experimental groups on pre-test.

Table 1: Significance of difference between the mean scores on pre-test of control and experimental groups

\begin{tabular}{ccccccc}
\hline Groups & N & Mean & SD & SE & t-value & p-value \\
\hline Control & 20 & 75.3 & 1.17 & 0.37 & $\mathbf{0 . 2 6 7}$ & $\mathbf{0 . 7 9}$ \\
Experimental & 20 & 75.4 & 1.20 & & \\
\hline Non-Significant & $\mathbf{d f}=\mathbf{3 8}$ & & \multicolumn{3}{c}{ table value of $\mathbf{t}$ at $\mathbf{0 . 0 5}=\mathbf{2 . 0 2}$}
\end{tabular}

Table 1 illustrates that the calculated value of $t$ was found to be 0.267 which is statistically non-significant $(p>0.05)$ because it is less than the table value of $t$ at 0.05 level. Hence the null hypothesis that "There is no significant different between the performance of control and experimental groups on pre-test" is accepted. The mean score values show that the students of both groups showed equal performance on pre-test.

Ho 2: There is no significance difference between the performance of high achievers of the control and experimental groups on pre-test.

Table 2: Significance of the difference between the mean scores on pre-test of the high achievers of the control and experimental groups

\begin{tabular}{ccccccc}
\hline Groups & N & Mean & SD & SE & t-value & p-value \\
\hline Control & 12 & 78.8 & 1.25 & 0.53 & $\mathbf{0 . 5 6 5}$ & $\mathbf{0 . 5 8}$ \\
Experimental & 12 & 79.1 & 1.35 & & table value of $t$ at $\mathbf{0 . 0 5}=\mathbf{2 . 0 7}$
\end{tabular}

Table 2 depicts that the calculated value of $\mathrm{t}$ was found to be 0.565 which is statistically non-significant $(p>0.05)$ because it is less than the table value of $t$ at 0.05 level. Hence the null hypothesis that "There is no significant different between the performance of higher achievers of control and experimental groups on pre-test" is accepted. The mean score values clearly indicate that the high achievers of the both groups showed equal performance on pre-test. 
Ho 3: There is no significant difference between the performance of low achievers of the control and experimental groups on pre-test.

Table 3: Significance of the difference between the mean scores on pre-test of the low achievers of the control and experimental groups

\begin{tabular}{ccccccc}
\hline Groups & N & Mean & SD & SE & t-value & p-value \\
\hline Control & 08 & 70.0 & 1.31 & \multirow{2}{*}{0.72} & $\mathbf{0 . 1 3 9}$ & $\mathbf{0 . 8 9}$ \\
Experimental & 08 & 69.9 & 1.55 & & & \\
\hline Non-Significant & $\mathbf{d f}=\mathbf{1 4}$ & & & table value of $\mathrm{t}$ at $\mathbf{0 . 0 5}=\mathbf{2 . 1 4}$
\end{tabular}

Non-Significant $\quad d f=14 \quad$ table value of $t$ at $0.05=2.14$

Table 3 depicts that the calculated value of $t$ was found to be 0.139 which is statistically non-significant ( $p>0.05)$ because it is less than the table value of $t$ at 0.05 level. Hence the null hypothesis that "There is no significant different between the performance of low achievers of the control and experimental groups on pre-test" is accepted. The mean score values unambiguously show that the low achievers of the both groups showed equal performance on pre-test.

Ho 4: There is no significant difference between the performance of the control and experimental groups on post-test.

Table 4: Significance of difference between the mean scores on post-test of control group and experimental group

\begin{tabular}{ccccccc}
\hline Groups & N & Mean & SD & SE & t-value & p-value \\
\hline Control & 20 & 81.4 & 1.62 & & & \\
Experimental & 20 & 91.8 & 1.80 & & & $\mathbf{1 9 . 2 1 *}$ \\
\hline
\end{tabular}

$\begin{array}{lll}* \text { Significant } & \text { df }=38 & \text { table value of } t \text { at } 0.05=2.02\end{array}$

Table 4 illustrates that the calculated value of $t$ was found to be 19.21 which is statistically significant $(\mathrm{p}<0.05)$ because it is greater than the table value of $t$ at 0.05 level. Hence the null hypothesis that "There is no significant different between the performance of control and experimental groups on post-test" is rejected. The mean score values plainly indicate that students of experimental group showed significantly excellent performance as compared to the control group on post-test.

Ho 5: There is no significant difference between the performance of high achievers of control and experimental groups on post-test.

Table 5: Significance of difference between the mean scores on post-test of high achievers 
of control and experimental group

\begin{tabular}{|c|c|c|c|c|c|c|}
\hline Groups & $\mathbf{N}$ & Mean & SD & SE & t-value & p-value \\
\hline Control & 12 & 83.3 & 1.49 & \multirow{2}{*}{0.62} & \multirow{2}{*}{$17.02 *$} & \multirow{2}{*}{0.000} \\
\hline Experimental & 12 & 93.9 & 1.56 & & & \\
\hline
\end{tabular}

*Significant $\quad$ df $=22$

table value of $\mathrm{t}$ at $0.05=\mathbf{2 . 0 7}$

Table 5 shows that the calculated value of $\mathrm{t}$ was found to be 17.02 which is statistically significant $(\mathrm{p}<0.05)$ because it is greater than the table value of $\mathrm{t}$ at 0.05 level. Hence the null hypothesis that "There is no significant different between the performance of higher achievers of control and experimental groups on post-test" is rejected. The mean score values clearly depict that the high achievers of the experimental group showed significantly excellent performance as compared to the high achievers of the control group on post-test.

Ho 6: There is no significant difference between the performance of low achievers of control and experimental groups on post-test.

Table 6: Significance of difference between the scores on post-test of low achievers of control group and experimental group

\begin{tabular}{ccccccc}
\hline Groups & N & Mean & SD & SE & t-value & p-value \\
\hline Control & 08 & 78.5 & 1.51 & & & \\
Experimental & 08 & 88.5 & 1.20 & & & $\mathbf{1 4 . 6 7 *}$ \\
\hline
\end{tabular}

*Significant $\quad$ df $=14 \quad$ table value of $t$ at $0.05=2.14$

Table 6 indicates that the calculated value of $\mathrm{t}$ was found to be 14.67 which is statistically significant $(\mathrm{p}<0.05)$ because it is greater than the table value of $t$ at 0.05 level. Hence null the hypothesis that "There is no significant different between the performance of low achievers of control and experimental groups on post test" is rejected. The mean score values plainly show that the low achievers of the experimental group showed significantly better performance as compared to the low achievers of control group on post test.

Ho 7: There is no significant difference between the performance of control and experimental groups on retention test.

Table 7: Significance of difference between the mean scores on retention test of control and experimental groups 


\begin{tabular}{ccccccc}
\hline Groups & N & Mean & SD & SE & t-value & p-value \\
\hline Control & 20 & 78.5 & 1.67 & & & \\
Experimental & 20 & 91.1 & 1.84 & & & $\mathbf{2 2 . 6 8 *}$ \\
\hline
\end{tabular}

*Significant $\quad$ df $=\mathbf{3 8}$

table value of $t$ at $0.05=2.02$

Table 7 illustrates that the calculated value of $t$ was found to be 22.68 which is statistically significant $(\mathrm{p}<0.05)$ because it is greater than the table value of $t$ at 0.05 level. Hence the null hypothesis that "There is no significant different between the performance of control and experimental groups on retention test" is rejected. The mean score values clearly indicate that the students of experimental group showed significantly excellent performance as compared to the students of control group on retention test.

Ho 8: There is no significant difference between the performance of high achievers of control and experimental groups on retention test.

Table 8: Significance of difference between the mean scores of higher achievers of control and experimental groups on retention test

\begin{tabular}{ccccccc}
\hline Groups & N & Mean & SD & SE & t-value & p-value \\
\hline Control & 12 & 80.3 & 1.56 & & & \\
Experimental & 12 & 93.1 & 1.38 & & & $\mathbf{2 1 . 2 9 *}$ \\
\hline
\end{tabular}

*Significant df $=22$

table value of $t$ at $0.05=2.07$

Table 8 depicts that the calculated value of $\mathrm{t}$ was found to be 21.29 which is statistically significant $(p<0.05)$ because it is greater than the table value of $t$ at 0.05 level. Hence the null hypothesis that "There is no significant different between the performance of higher achievers of control and experimental groups on retention test" is rejected. The mean score values obviously show that the high achievers of the experimental group showed significantly excellent performance as compared to the high achievers of control group on retention test.

Ho 9: There is no significant difference between the performance of low achievers of control and experimental groups on retention test.

Table 9: Significance of difference between the mean scores of low achievers of control and experimental groups on retention test 


\begin{tabular}{|c|c|c|c|c|c|c|}
\hline Groups & $\mathbf{N}$ & Mean & SD & SE & t-value & p-value \\
\hline Control & 08 & 75.8 & 1.04 & \multirow{2}{*}{0.53} & \multirow{2}{*}{$23.13 *$} & \multirow{2}{*}{0.000} \\
\hline Experimental & 08 & 88.0 & 1.07 & & & \\
\hline
\end{tabular}

*Significant

Table 9 shows that the calculated value of $t$ was found to be 23.13 which is statistically significant $(\mathrm{p}<0.05)$ because it is greater than the table value of $t$ at 0.05 level. Hence the null hypothesis that "There is no significant different between the performance of low achievers of control and experimental groups on retention test" is rejected. The mean score values clearly indicate that low achievers of the experimental group showed significantly better performance as compared to the low achievers of control group on retention test.

\section{Disussion}

The purpose of the study was to examine the explore the effectiveness of multimedia in the development of teachers training institutes at tertiary level in Khyber Pakhtunkhwa. The study was experimental in nature and that is why Pretest-Post-test Equivalent Group Design was used. Sample students were divided into two groups i.e. control group and experimental group on the basis of pre-test. Both the groups were taught through usual method by two teachers of the same qualifications and teaching experience.. During the experiment, multimedia was used only for the experimental group. This experiment was continued for six weeks. After the completion of the experiment, the principal researcher administered a post-test immediately to examine whether students of experimental group have learnt well as compared to the students of control group or not. For this purpose the teachers made question paper covering the four units of teacher education which were taught during treatment for the both groups. After two weeks, again the principal researcher along with other two teachers again administered the same post-test with slight modifications in the sequence of the questions as a retention test to the students of both groups. In this way data was collected, organized, tabulated, analyzed and compared.

Table 1 indicates that there is no significant difference between the mean scores of experimental and control group on pre-test. The calculated t-value was found to be 0.267 which is non-significant ( $p>0.05$ ) at 0.05 level of confidence. Therefore it clearly shows that there is no significant difference between the performance of students of experimental (mean=75.4) and control (mean=75.3) group on pre-test. Thus it can be concluded that performance of students of the experimental and control groups was same on pre-test. Therefore, the null hypothesis "there is no significant difference between the performance of experimental and control group on pre-test" is accepted.

Table 2 shows that there is no significant different between the performance of higher achievers of control and experimental groups on pre-test. The calculated t-value was found to be 0.565 which is non-significant $(\mathrm{p}>0.05)$ at 0.05 level of confidence. Thus it unambigously shows that there is no significant difference between the performance of higher achievers of 
control (mean=78.8) and experimental (mean=79.1) groups on pre-test. Therefore, the null hypothesis "there is no significant difference between the performance of higher achievers of control and experimental groups on pre-test" is accepted.

Table 3 depicts that there is no significant different between the performance of low achievers of control and experimental groups on pre-test. The calculated t-value was found to be 0.139 which is non-significant $(p>0.05)$ at 0.05 level of confidence. Therefore it plainly indicates that there is no significant difference between the performance of higher achievers of control (mean=70.0) and experimental (mean=69.9) groups on pre-test. Therefore, the null hypothesis "there is no significant difference between the performance of low achievers of control and experimental groups on pre-test" is accepted.

Table 4 indicates that there is significant difference between the mean scores of experimental and control group on post-test. The calculated t-value was found to be 19.21 which is significant $(\mathrm{p}<0.05)$ at 0.05 level of confidence. Therefore it clearly shows that there is significant difference between the performance of students of experimental and control groups on post-test. Hence the result reveals that the students of experimental group (mean=91.8) showed better performance as compared to the students of control group (mean=81.4). Therefore, the null hypothesis "there is no significant difference between the performance of experimental and control group on post-test" is rejected.

Table 5 illustrates that there is significant difference between between the performance of higher achievers of control and experimental groups on post-test. The calculated t-value was found to be 17.02 which is significant $(\mathrm{p}<0.05)$ at 0.05 level of confidence. Hence it obviously indicates that there is significant difference between the performance of higher achievers of control and experimental groups on post-test. Hence the result reveals that the students of experimental group (mean=93.9) showed better performance as compared to the students of control group (mean=83.3). Therefore, the null hypothesis "there is no significant difference the performance of higher achievers of control and experimental groups on post-test" is rejected.

\section{Conclusions}

In the light of statistical analysis and findings of the study, the following conclusions were drawn:

1. Multimedia based teaching learning technique is more effective and successful as compared to the traditional teaching method. Students of experimental group showed extraordinary performance than the students of control group. Through multimedia based teaching, students were found more attentive and motivated.

2. Low achievers in multimedia based teaching method showed significant performance as compared to the low achievers taught by traditional method. Therefore, multimedia based teaching was found to be more effective method for teaching to the low achievers as compared to traditional method of teaching. 
3. Higher achievers in multimedia based teaching technique showed significant supremacy over high achievers taught by traditional method. Therefore, multimedia based teaching method was found to be more effective method to the higher achievers as compared to traditional method of teaching.

4. Retention of the students of experimental group was found significantly better than that of the students of control group. In addition, it was also found that retention of the students of experimental group was found significantly better as a whole, for low achievers and for higher achievers.

\section{Concluding Remarks}

In nutshell, multimedia plays a crucial and fundamental role in strengthening and improving the educational attainment of the student teachers in teachers training institutes. There is a significant positive effect of multimedia on the academic achievement of student teachers. Multimedia was found more effective and successful in the educational attainment of prospective teachers. By the use of multimedia, motivational level of the student teachers was increased. It was found more beneficial in clarifying the concepts of student teachers easily. In short, multimedia based teaching learning method is very effective for the prospective teachers.

\section{Recommendations}

Keeping in view the above conclusions, the researchers made the following recommendations:

1. As it was found that multimedia play a crucial role in strengthening and improving teaching learning process and help in clarifying difficult concepts easily. In addition, multimedia based teaching method increases the motivational level of the students and therefore, it is strongly recommended that all the teachers should utilize multimedia in their teaching learning process regularly.

2. Availability of multimedia in our institutions is the key problem. Most of the multimedia is not available in our institutes. Therefore it should be provided to all schools on the emergency basis. Computers, multimedia, overhead projectors, educational television, radios, models, pictures, maps, flip charts, charts, film strips, educational software, flash cards etc should be provided to all schools immediately.

3. A special training programme should be introduced for the effective use of multimedia and other educational technologies. All the in-service teachers should be provided training opportunities to make them proficient in using multimedia.

4. A compulsory subject regarding the preparation or utilization of multimedia should be introduced in teacher training programmes at each level so that the prospective teachers may be trained in using multimedia.

5. Alternate power supply should be provided to each school for the successful integration of electronic multimedia. For this purpose, power generators should be provided to each school on the emergency basis.

6. Physical and technical infrastructure should be designed in such a way that multimedia may be used effectively. 
7. Special room should be constructed for keeping educational technologies.

8. A special staff should be appointed by the higher authority to check the utilization of multimedia by the teachers in teachers training institutes.

9. Special budget should be provided to teachers training institutes by the government to purchase multimedia and other educational technologies.

\section{Recommendation for Further Studies}

1. It is recommended that such type of study should be conducted at secondary and higher secondary level.

2. It is also recommended that such type of study should be conducted in other provinces of the country.

\section{References}

Aggarwal, J. C. (1993). Development and Planning of Modern Education. Vikas Publishing, New Delhi. pp. 260-261

Aggarwal, Y. P. (1988). Research in Emerging Fields of Education. Sterling Publishers, New Delhi. pp. 17-18

A.I.O.U. (1998). Secondary Education. Study Guide for M.Ed, Code No. 827. Faculty of Education, Teacher Education Department, Allama Iqbal Open University, Islamabad.

Bennet, C. (2000). Preparing Teachers for Culturally Diverse Students. Journal of Teaching and Teacher Education. Vol. 16. p.59

DCTE, N.W.F.P. (2009). Directory of Teacher Education/Training Institutes in N.W.F.P. Supported under STEP Project implemented by UNESCO-Pakistan and funded by USAID-Pakistan. pp.8, 10-12

Farrant, J. S. (1990). Principles and Practices of Education, $2^{\text {nd }}$ Edition, London, UK. English Language Book Society, Longman. p.169

Fletcher, J. D. (2003). Evidence for learning from technology-assisted instruction. In H. F. O'Neil, Jr. \& R. S. Perez (Eds.), Technology applications in education: A learning view. Mahwah, NJ: Lawrence Erlbaum Associates.

Frank and Wagnalls, (1987). New Encyclopedia of Education. Pergamon Press Inc, Company, inc., Manila. p. 125

Good, C. V. (1973). Dictionary of Education. $3^{\text {rd }}$ Ed., McGraw-Hill Book Company, New York.

Govt. of Pakistan. (1959). Report of the Commission on National Education. Ministry of Education, Karachi.

Govt. of Pakistan. (1995). Elementary Teacher Education, Curriculum and Syllabus for Primacy Teacher Certificate. Curriculum Wing, Ministry of Education, Islamabad. P.1

Iqbal, M. Z. (1996). Teacher Training in the Islamic Perspective. Institute of Policy Studies and international institutes of Islamic Thought, Islamabad. pp.197-249

Kline, F. (1994). Multimedia in Teacher education: Coping with the human element. In J. Willis, B. Robin \& D. Willis. (Eds.). Technology and Teacher Education Annual, 1994.Charlottesville, VA: Association for the Advancement of Computing in Education. pp. 759-763. 


\section{Macrothink}

International Journal of Learning \& Development

ISSN 2164-4063

2012, Vol. 2, No. 6

Lewis, J. H., \& Hosie, P. J. (1994). Interactive video and interactive multimedia in higher education in Singapore: A case study. In C. McBeath \& R. Atkinson (Eds), $2^{\text {nd }}$ International Interactive Multimedia Symposium. pp.284-289

Mayer, R. E. (2001). Multimedia Learning. New York: Cambridge University Press.

Norton, P. B. (1985). Encyclopedia of Britannica. International Standard Book, Chicago. pp. 440-445

Rouet, J. F., Levonen, J. J., \& Biardeau, A. (2001). Introduction. In J. F. Rouet, J. J. Levonen, \& A. Biardeau (Eds.), Multimedia learning: Cognitive and instructional issues (pp. 1-8). London: Pergamon.

Shahid, S. M. (2007). Teacher Education in Pakistan. Majid Book Depot, Urdu Bazaar Lahore.

Sheikh, M. \& Rasool, M. G. (1998). Allied Material for Teacher Education in Pakistan, Islamabad, Pakistan, Symaz Printers, Allama Iqbal Open University, Islamabad.

Salinger, M. (2004). Developing and using content in technology enhanced learning environments. In I.P.A Cheong, H.S. Dhindsa, I. J. Kyeleve, O. Chukwu (Eds), Globalization trends in Science, Mathematics and Technical education, Gadong: University Brunei Darussalam. pp.24-37

Suleman, Q., Aslam, H. D., Javed, T. \& Hussain, I. (2011). Barriers to the Successful Integration of Educational Technology in Teaching Learning Process at Secondary School Level in Khyber Pakhtunkhwa Pakistan. International Journal of Research in IT \& Management, 1 (8), 97-119.

Vallikkad, S. (2009). Information \& Communication Technology for Teacher Education. Kanishka Publishers, Distributors. New Delhi-110002.

Venkataiah, N. (1996). Educational Technology. APH Publishing Corporation. 5, Ansari Road, Daryagang, New Delhi-110002

Zeichner, K. (1983). Alternative Paradigms of Teacher Education. Journal of Teacher Education 34; 3-9 http://jte.sagepub.com.cyber.usask.ca/cgi/reprint/34/3/3 